\title{
Quantity, composition, and source of sediment collected in sediment traps along the fringing coral reef off Molokai, Hawaii
}

\author{
Michael H. Bothner ${ }^{\text {a,* }}$, Richard L. Reynolds ${ }^{\text {b }}$, Michael A. Casso ${ }^{\text {a }}$, \\ Curt D. Storlazzi ${ }^{\mathrm{c}}$, Michael E. Field ${ }^{\mathrm{c}}$ \\ ${ }^{a}$ US Geological Survey, 384 Woods Hole Road, Woods Hole, MA 02543, USA \\ ${ }^{\mathrm{b}}$ US Geological Survey, MS 980, Box 25046, DFC, Denver, CO 80225, USA \\ ${ }^{\mathrm{c}}$ US Geological Survey, Pacific Science Center, 400 Natural Bridges Drive, Santa Cruz, CA 95060, USA
}

\begin{abstract}
Sediment traps were used to evaluate the frequency, cause, and relative intensity of sediment mobility/resuspension along the fringing coral reef off southern Molokai (February 2000-May 2002). Two storms with high rainfall, floods, and exceptionally high waves resulted in sediment collection rates $>1000$ times higher than during non-storm periods, primarily because of sediment resuspension by waves. Based on quantity and composition of trapped sediment, floods recharged the reef flat with land-derived sediment, but had a low potential for burying coral on the fore reef when accompanied by high waves.

The trapped sediments have low concentrations of anthropogenic metals. The magnetic properties of trapped sediment may provide information about the sources of land-derived sediment reaching the fore reef. The high trapping rate and low sediment cover indicate that coral surfaces on the fore reef are exposed to transient resuspended sediment, and that the traps do not measure net sediment accumulation on the reef surface.
\end{abstract}

Published by Elsevier Ltd.

Keywords: Coral reef; Sediment; Sediment traps; Chemical composition; Magnetic properties; Molokai

\section{Introduction}

The fringing coral reef off Molokai's southern coast (Fig. 1) has been the focus of a comprehensive USGS study to understand the dynamics of sediment transport and its impact on coral health (Ogston et al., 2004; Storlazzi et al., 2004a). This reef was selected in part because changes in land use adjacent to the reef have resulted in an increase of erosion and delivery of terrestrial sediment to the reef system that is recognized as a potential stress to the environmental health of the reef. The scientific literature describing the health of coral reefs includes numerous studies that reach different conclusions concerning the impact of suspended sediment and sedimentation. Degraded reef health that is related to sedimentation has been shown to

\footnotetext{
* Corresponding author. Tel.: +1 508457 2240; fax: +1 5084572309.

E-mail address: mbothner@usgs.gov (M.H. Bothner).
}

result from burial or smothering (Rogers, 1990; Nugues and Roberts, 2003), high turbidity (Hayward, 1982; Bak, 1978), inhibition of larval settlement (Wittenberg and Hunte, 1992), and inputs from sewage (Risk and Erdman, 2000). In some settings, sediments have no apparent negative impact because certain species have been shown to tolerate high sediment loadings (Woolfe and Larcombe, 1998). For some species of coral that can utilize sediment-bound organic matter as a source of food (Rosenfeld et al., 1999; Anthony, 2000), suspended sediment can be a benefit to coral health.

The summary by Roberts (2001) of Molokai's development from the first Polynesian settlements, about $600 \mathrm{CE}$ to the present, describes an increasing rate of erosion related to intensive farming, the clearing of native vegetation, and the introduction of both feral and domesticated grazing animals. In 1934, a 1500-yard solid wharf that disrupts the westerly along-shore current was constructed at 


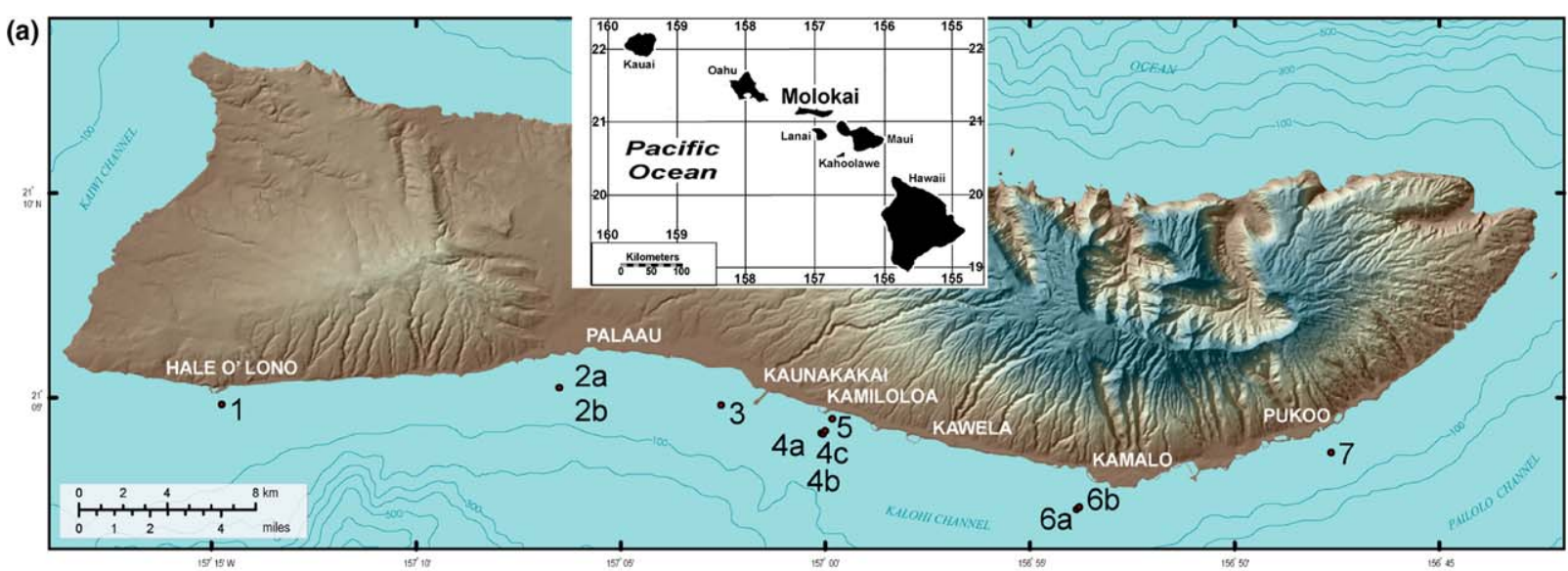

(b)

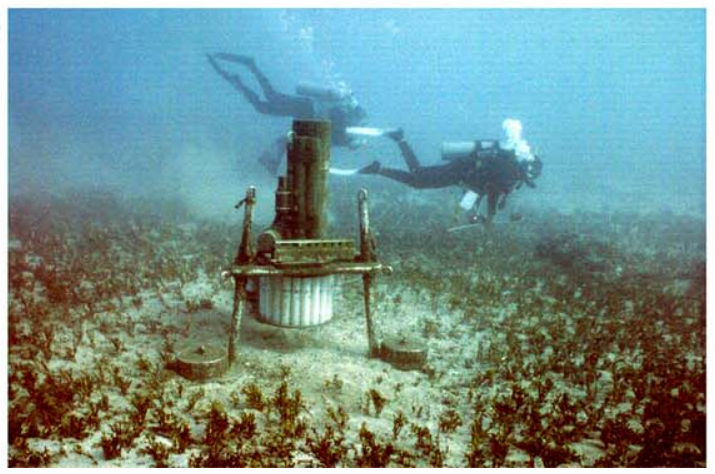

(c)

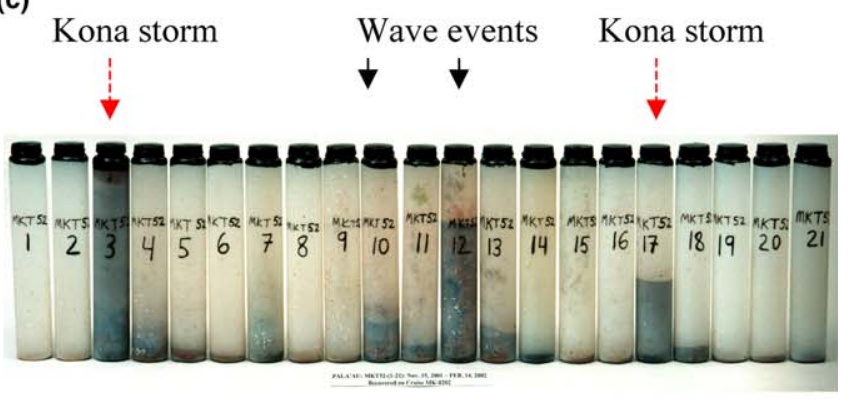

Fig. 1. (a) Sediment trap locations along the fringing reef off Molokai and inset map of Hawaiian Islands. (b) A time-series sediment trap was deployed at sites $2 \mathrm{~b}$ and $4 \mathrm{~b}$ at water depths of about $12 \mathrm{~m}$. The trap mouth is $1.3 \mathrm{~m}$ above bottom. (c) Sampling bottles from the time-series sediment trap deployed at site $2 \mathrm{~b}$ between November 15, 2001 and February 14, 2002. Each 500-ml bottle collected for about 4.5 days. The variability in amounts and composition of the sediment (gray in the image) are discussed in Section 4.

Kaunakakai (Fig. 1) in the central part of Molokai's southern coast (Roberts, 2001). The resulting greater delivery of sediment to the reef system and reduced rate of sediment and nutrient removal by along-shore currents have been cited as contributing factors to the low coral coverage along one anomalous section of the reef at Kamiloloa (Jokiel et al., 2004).

Kona ("from the south") storms are rare, but they typically contribute a large proportion of the annual rainfall to the arid land region of central and west Molokai adjacent to the reef system (Ogston et al., 2004). Following heavy rains in this region, the normally dry valleys fill with sediment-laden water and discharge to the coast and reef flat. A visible result of heavy rains is a reddish plume of flood-discharged suspended sediment in surface waters that extends from the shoreline to the reef crest and beyond (Field et al., in press).

The coverage by live coral along the fore reef off the south coast of Molokai is in the range of $90-98 \%$ along much of its 53-km length (Jokiel, 2004), diminishing significantly at the east and west ends due to greater exposure to large waves (Storlazzi et al., 2004b). This is the longest continuous fringing reef in the Hawaiian Island chain (Roberts, 2001). In an anomalous 6-km wide section in the central region of the reef off the town of Kaunakakai (Fig. 1), the coral coverage is $<12 \%$ (Jokiel, 2004). This same section of the reef is adjacent to an area of the reef flat that chronically exhibits high levels of suspended sediment, but the linkage between low coral coverage and suspended sediment transport has not been confirmed (Ogston et al., 2004).

The objective of this study was to gain information about the frequency, cause, and relative intensity of sediment mobility/resuspension events within the Molokai fringing reef system using time-series sediment traps and standard tube traps. During the 2-year period of this study, there were two major Kona storms (November 27-28, 2001 and January 29-30, 2002). These storms brought heavy rain ( $>2 \mathrm{~cm} /$ day) and flooding to the southern side of Molokai adjacent to the reef and caused the largest waves on the fore reef during the study period (Field et al., in press). These storms presented an opportunity to compare changes in composition of trapped material and thereby to determine the contribution of flood-derived material to resuspended sediment across the reef. The time-series traps provided 4.5-day resolution of the amount and composition of sediment trapped before, during, and following major storm events.

We emphasize that the information derived from sediment traps in this study is a relative measure of sediment mobility/resuspension. This limitation should be kept in 
mind because the efficiency of traps for sequestering particles and the degree of trapping bias in favor of the more rapidly settling particles have not been quantified in an environment dominated by wave-induced oscillatory currents that resuspend bottom sediments. A field study by Baker et al. (1988) described trapping characteristics in unidirectional currents (up to $80 \mathrm{~cm} / \mathrm{s}$, similar in magnitude to the speed of wave-induced oscillatory currents in this study), and found that with increasing current speeds, the efficiency of sediment trapping decreases, and the collection bias favoring coarser, more rapidly settling particles, increases. Their experimental design avoided the complications imposed by wave-induced currents and bottom sediment resuspension that are typical of the Molokai reef. In the high-energy setting of the Molokai reef, near-bottom traps ( $\leqslant 1.3 \mathrm{~m}$ above bottom) do not measure "sedimentation rate" on the reef surface, although this term is commonly used to describe trap results in the coral reef literature. "Collection rate" is a more appropriate term because particles falling into a trap are retained in a protected environment, whereas particles falling to the reef surface are exposed to turbulence and may be resuspended and removed as the next wave passes.

\section{Setting}

Two recent papers (Ogston et al., 2004; Storlazzi et al., 2004a) describe the geologic setting and oceanographic conditions of the reef complex along the southern coast of Molokai and are briefly summarized here. The reef flat is a shallow $(0-2 \mathrm{~m})$ platform extending from the shoreline to a distance up to $1.5 \mathrm{~km}$ seaward in the vicinity of Kaunakakai. The inner reef flat is covered with a thin veneer of silty brown sediment derived mostly from the island (Calhoun and Field, 2002). The outer region of the reef flat has a subdued spur-and-groove morphology with maximum relief of about $1 \mathrm{~m}$ (Storlazzi et al., 2003). Carbonate sands occur in the grooves, and low-lying spurs are typically covered by algae and small amounts of live coral (Storlazzi et al., 2004a).

The reef crest, consisting of large coral heads and coral or algae encrusted rubble in $0-2 \mathrm{~m}$ water depth, is generally well developed along the outer edge of the reef flat and absorbs much of the energy from deep-water waves (Storlazzi et al., 2004a). Sediments on the fore reef are primarily sand-sized carbonate fragments derived from the reef (Calhoun and Field, 2002) that exist within depressions and crevices in the spur-and-groove reef structure.

Because of the east-west orientation of the reef system off Molokai's southern shore, waves influencing sediment resuspension are from four primary sources: Northeast Trade winds, southern swell, Kona storm swell, and North Pacific swell (Moberly and Chaimberlin, 1964; Storlazzi et al., 2004b). Large swells from the North Pacific refract around the east and west ends of the island to impact Hale O'lono and Pukoo (Fig. 1). Northeast Trade-wind-driven waves and currents frequently resuspend the reef flat sedi- ment. Resuspension of reef flat sediment is greatest during periods of high tide because offshore wave energy can more effectively propagate over the reef crest (Ogston et al., 2004; Storlazzi et al., 2004a; Presto et al., 2006). The net flux of sediment resuspended on the reef flat is to the southwest and offshore along south-central Molokai (Ogston et al., 2004).

\section{Methods}

Two types of sediment traps were used. The simpler tube trap consisted of a clear plastic tube $60-\mathrm{cm}$ long (reduced to $30 \mathrm{~cm}$ on the shallow reef flat) having an internal diameter of $6.7 \mathrm{~cm}$. A honeycomb baffle (cells $0.5-\mathrm{cm}$ diameter, 7.6$\mathrm{cm}$ long) consisting of phenolic resin and treated with antifouling paint was placed in the top of the traps to reduce turbulence and to prevent fish occupation. These traps were either hose-clamped to steel rods driven vertically into the sediment or reef surface, attached to cinder blocks, or fixed to an instrumented tripod. The base of the trap was in contact with the reef surface so trap openings were $60 \mathrm{~cm}$ above bottom $(30 \mathrm{~cm}$ on the shallow reef flat). Reproducibility of the collection rate measurement by tube traps was evaluated by setting duplicate traps on seven occasions. The average difference in collection rate between pairs was $11 \%$. Tube traps were used all along the fore reef and on the reef flat.

A programmable time-series trap was also used that had a 20-cm ID collection cylinder with an overall length of $75 \mathrm{~cm}$. A funnel, placed in the bottom $15 \mathrm{~cm}$ of the cylinder, directed settling particulate material into one of 21 plastic bottles $(500 \mathrm{ml}$ each). The sampling bottles were on a carousel that rotated a new sampling bottle (McLane Research Laboratories, Inc., 2004) under the funnel after a period of about 4.5 days (Fig. 1). The trap opening was $1.3 \mathrm{~m}$ above bottom. Time-series traps were positioned at Kamiloloa (site 4a) and Palaau (site 2b) at about $12 \mathrm{~m}$ water depth. The time-series trap could be easily detached from the support tripod (Fig. 1) by scuba divers for servicing between deployments ( every 3 months).

Self-contained NIWA Dobie-A wave gauges were deployed at six locations that were also occupied by sediment traps. The wave gauges were fixed to the leg of an instrumented tripod or clamped to a mount specifically designed to attach the gauges to the sea floor. Storlazzi et al. (2004a) describe the methods used to evaluate the wave spectrum and to determine dominant wave period, significant wave height, and bottom stress. Wave orbital velocities were calculated using Stokes second-order wave theory. Peak wave-induced bottom shear stress was calculated using the methodology proposed by Jonsson (1966) and Nielsen (1992).

\subsection{Sample processing technique}

Different methods were used for sample processing and determination of sediment collection rate $\left(\mathrm{g} / \mathrm{m}^{2} /\right.$ day $)$ 
depending on the gross amount of material collected in each trap. The largest samples, consisting of full tubes of sediment, were X-rayed at the Molokai General Hospital, split lengthwise, photographed, and sub-sampled based on stratigraphic structures using titanium tools. The more typical trap samples were rinsed through a $1-\mathrm{mm}$ plastic sieve that removed macro algae and filamentous organic matter. The material passing the sieve was split using a 4-funnel rotary splitter (Honjo, 1980). Trace metal clean procedures were used for all steps in sample preparations. Calculations of salt content were made from measured salinity of the interstitial water and the water loss on freeze-drying. Collection rates are reported on a salt-free basis. Several wet splits were retained for texture and other analyses.

\subsection{Size and carbonate analysis}

Wet sediment samples were sieved to separate sand and coarser particles from the silt and clay. The sand fraction was analyzed using a 2-m settling tube, and the silt and clay fractions were determined using a Beckman Coulter Counter. Carbonate content was determined on dry samples using a UIC coulometer. Details of the methods are reported in Barber (2002).

\subsection{Metal analysis}

In the laboratory, sub-samples of the sediment-trap material were freeze-dried and ground in an agate mortar and pestle. The dry powders were completely dissolved in acids ( $\mathrm{HF}, \mathrm{HNO}_{3}, \mathrm{HCl}$, and $\mathrm{HClO}_{4}$ ) using a procedure similar to the one described by Briggs and Meier (1999). Metal concentrations were determined using an inductively coupled plasma-mass spectrometer (ICP-MS) procedure for multiple elements described in Lamothe et al. (1999). The results were corrected for salt content.

\subsection{Magnetic properties}

Measures of the abundance of magnetite, and its magnetic grain size (magnetic domain state), are provided by magnetic-property measurements (see Thompson and Oldfield, 1986). For this study, the measurements were made on dried bulk sediment packed into $3.2-\mathrm{cm}^{3}$ plastic cubes and normalized for sample mass. Isothermal remanent magnetization (IRM) is a measure of the quantity of magnetite having sufficiently large magnetic grain size (greater than about $30 \mathrm{~nm}$ ) to carry remanence following exposure to a strong magnetic field ( $0.3 \mathrm{~T}$ in this study). Remanent magnetization was measured using a $90-\mathrm{Hz}$ spinner magnetometer with a sensitivity of about $10^{-5} \mathrm{~A} / \mathrm{m}$. Anhysteretic remanent magnetization (ARM) is another measure for magnetite abundance, and it is particularly sensitive to single domain and small pseudo-single domain grain sizes of magnetite. ARM was imparted in a DC induction of $0.1 \mathrm{mT}$ in the presence of a decaying alternating induction from 100 to $0 \mathrm{mT}$.

\section{Results and discussion}

\subsection{Tube traps}

The average sediment collection rates measured for sequential 3-month deployments between February 2000 and May 2002 (Fig. 2) indicate regional differences in sediment mobility. The tube trap openings where at $0.6 \mathrm{~m}$ above the bottom (MAB) except were noted. The pink bar in each sub-plot shows the collection rates during the deployment period that included the Kona storms of November 2001 and January 2002. Those storms brought exceptionally high waves to most areas along the reef and flooding rains to the normally dry south side of Molokai.

During Kona storms the 3-month average collection rate at $0.6 \mathrm{~m}$ above bottom was about 10 times higher than during pre-storm deployment periods, but showed considerable variability (Fig. 2c). Collection rates during Kona storms increased by 1.3 times at Palaau (site 2a) and by 39 times at Kamalo (site 6b). The traps at Hale O'lono (site 1), Kamiloloa (site 4c), and Pukoo (site 7) were full at the time of recovery, so the collection rates during the storm period are minimum estimates.

During the non-storm periods, collection rates in tube traps were highest at Hale O'lono and Pukoo (about 4000 and $1500 \mathrm{~g} / \mathrm{m}^{2} /$ day, respectively) on the wave-exposed west and east ends of the reef, and lowest at Kamalo $\left(5 \pm 2 \mathrm{~g} / \mathrm{m}^{2} /\right.$ day). Non-Kona storm collection rates were intermediate at Kamiloloa (site $4 \mathrm{~b}, 33 \pm 10 \mathrm{~g} / \mathrm{m}^{2} /$ day) and Palaau (site $2 \mathrm{a}, 160 \pm 121 \mathrm{~g} / \mathrm{m}^{2} /$ day). During the deployment beginning in April 2001, when recovery of wave and trap data were high, the sediment trap collection rates at these locations varied from highest to lowest in the same rank order as the average wave-induced bottom stress (blue dots in Fig. 2b). This supports our assumption that near-bottom sediment trap collection rates in the study area are controlled primarily by resuspension of bottom sediment in response to wave-induced bottom stress.

The increasing capacity for waves to resuspend sediments as water depth decreases is illustrated with trap results from Kamiloloa. Traps at $4.9 \mathrm{~m}$ water depth (site $4 c)$ collected at a rate 22 and $>33$ times higher than identical nearby traps at $10.1 \mathrm{~m}$ water depth (site $4 \mathrm{~b}$ ). For a 132day period, when wave data were available at both sites, the calculated integrated bottom stress above the threshold for resuspending mixed carbonate sand $\left(0.11 \mathrm{~N} / \mathrm{m}^{2}\right.$, for 2.5 phi and finer) was about 4.6 times higher at $4.9 \mathrm{~m}$ than at $10.1 \mathrm{~m}$.

The collection rate is also dependent on sediment availability. At Palaau, one trap was at $9.6 \mathrm{~m}$ water depth on a coral spur (site $2 a$ ), which was covered by $95 \%$ living coral with, at most, a dusting of fine sediment except in deep crevices of the reef surface. The other was approximately $12 \mathrm{~m}$ away at $12.6 \mathrm{~m}$ water depth, in a sand channel (site $2 \mathrm{~b}$ ) floored by freshly formed ripples, an indication of active sediment movement. Although the calculated bottom stress on the shallower coral spur is considerably higher than in 


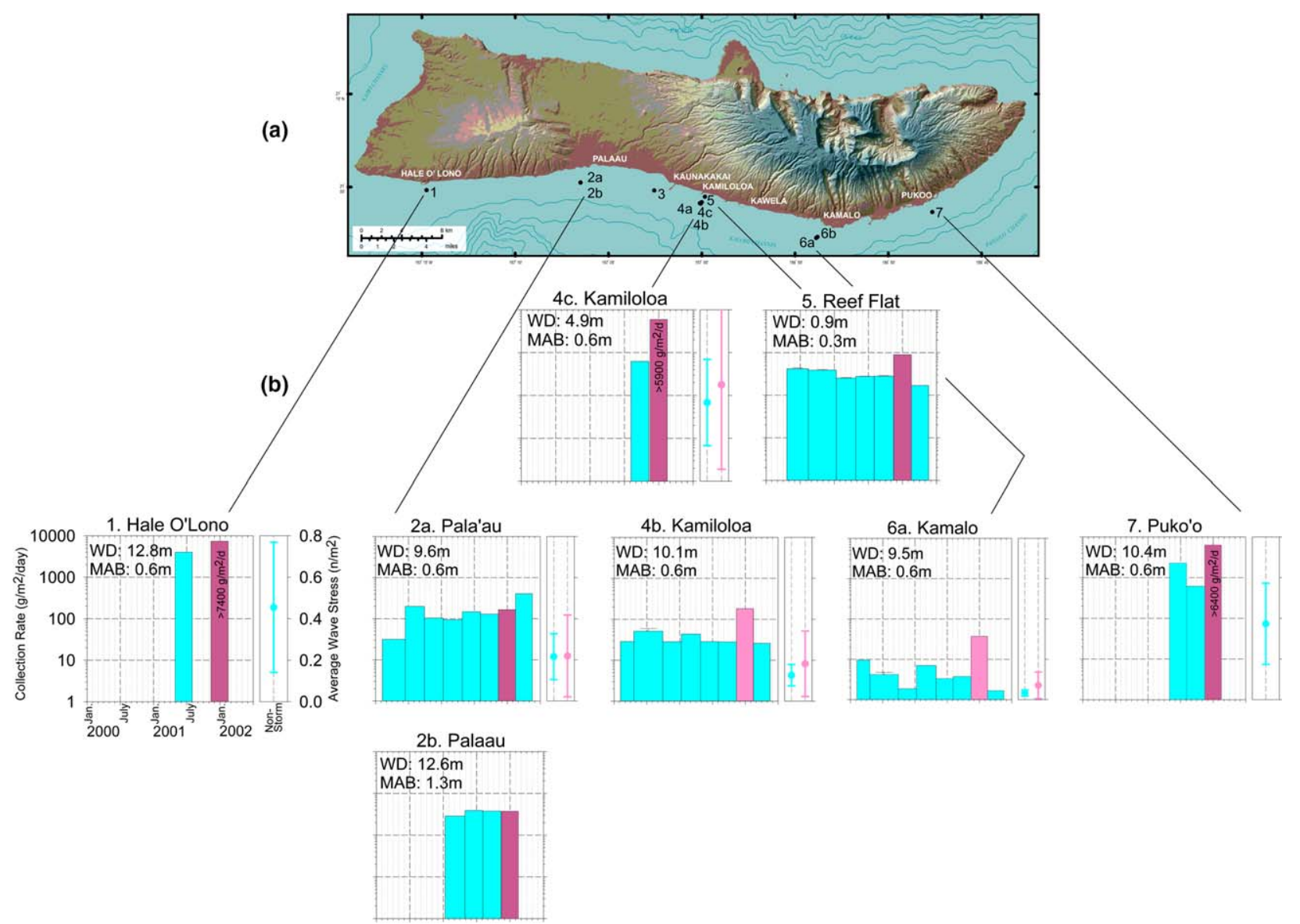

Fig. 2. (a) Hillshaded topographic map of Molokai showing the locations of sediment traps. (b) Collection rate (bars) during successive 3-month trap deployments at eight locations along the reef. Data from non-storm periods are shown in blue. Data from the deployment containing Kona storms are shown in pink when the traps at three locations were completely filled at the time of recovery. Average wave-induced bottom stress is shown in similarly colored dots. Higher bottom stress at the wave-exposed east and west ends of the reef, and lower bottom stress in the more protected central area explain the regional differences in collection rate. High bottom stress during Kona storms generated higher collection rates at most locations. WD is water depth in $\mathrm{m}$; MAB indicates height of trap opening in meters above bottom.

the sand channel, the collection rates were only $1 / 3$ of those measured in the deeper trap adjacent to a sediment supply. On the reef flat (Fig. 2, site 5) high collection rates are related to the combination of a large inventory of finegrained sediment, shallow water, wind waves, and occasional long-period ocean swell that resuspended sediment particularly at high tide (Storlazzi et al., 2004a; Ogston et al., 2004).

\subsection{Tube trap composition}

The Kona storms completely filled some of the tube traps, providing sufficient sediment volume to identify and sample individual layers. X-rays of trap samples (Fig. 3) were taken at the Molokai General Hospital and photographs of split trap samples were subsequently taken in the laboratory. Selected horizons were analyzed for texture and carbonate content.

The sediment trap material collected from the reef flat off Kamiloloa (Fig. 3) during the Kona storm period had the highest non-carbonate fraction and the highest silt + clay percentage among all the traps deployed in this program. This trap had an average non-carbonate faction of $76 \% \pm 4 \%$, significantly above the pre-storm average of $60 \% \pm 4 \%$ and a single post-storm value of $58 \%$. This observation is consistent with the hypothesis that landderived mud is delivered to south Molokai's reef flat during the floods that typically accompany Kona storms (Ogston et al., 2004).

The flood signal was also measurable at locations farther offshore. The sediment trap at site $4 \mathrm{c}$ in $4.9 \mathrm{~m}$ water depth on the fore reef off Kamiloloa, $100 \mathrm{~m}$ seaward of the reef crest, has a distinct horizon at $27-29 \mathrm{~cm}$ that is visible in the trap X-ray and in the photograph of the split trap sample (Fig. 3 site 4c). The steep dip of this horizon and others that are nearly parallel to it may result from a slight tilt of the trap from vertical (typically $<10^{\circ}$ ) during deployment that would allow rapidly settling particles to preferentially accumulate along one side of the trap. Neither the stratigraphy nor the tilt was disturbed during collection or transport from the reef to the laboratory because the trap was completely filled with seawater and capped. 

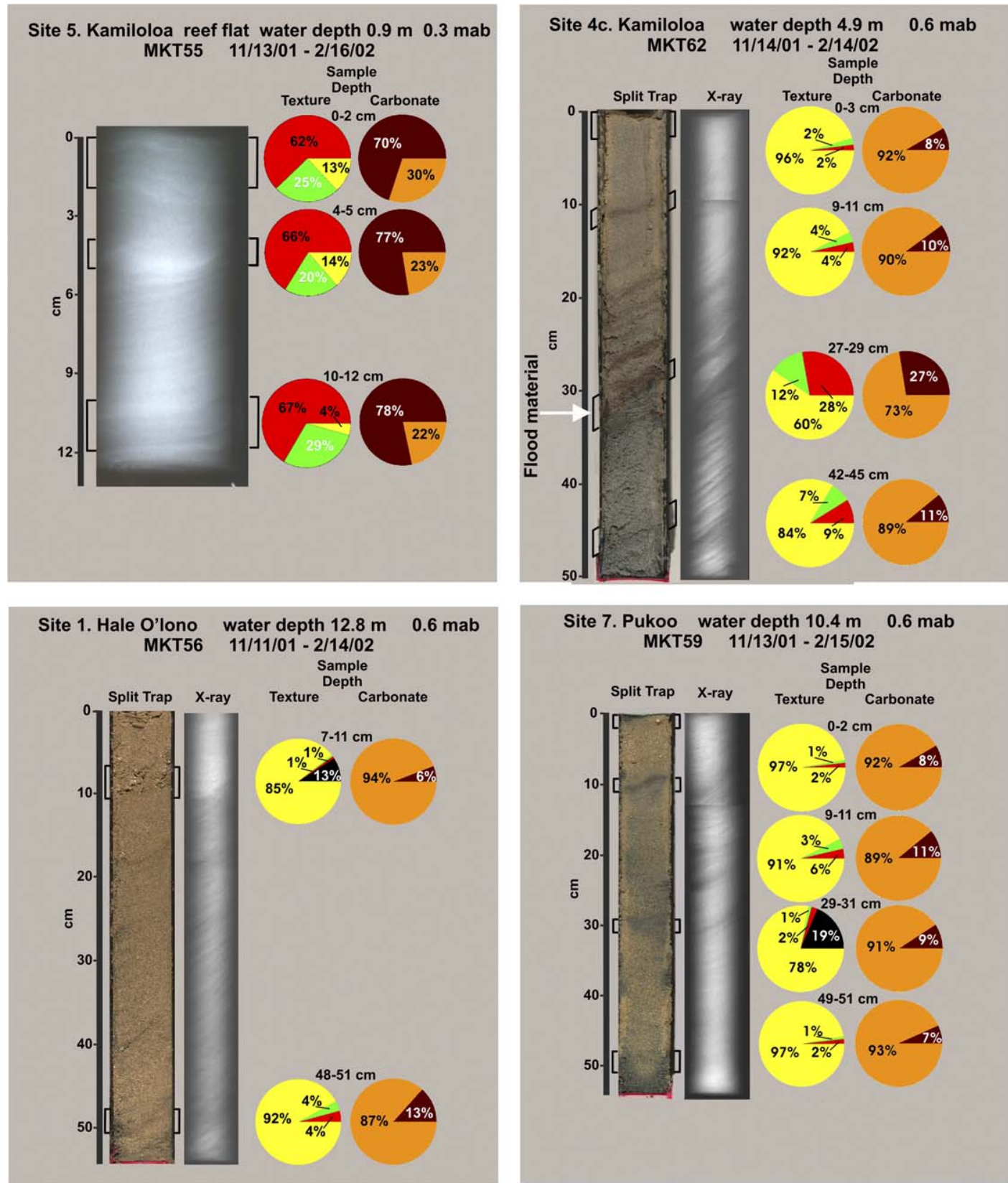

Site 7. Pukoo water depth $10.4 \mathrm{~m} \quad 0.6 \mathrm{mab}$ MKT59 11/13/01 - 2/15/02

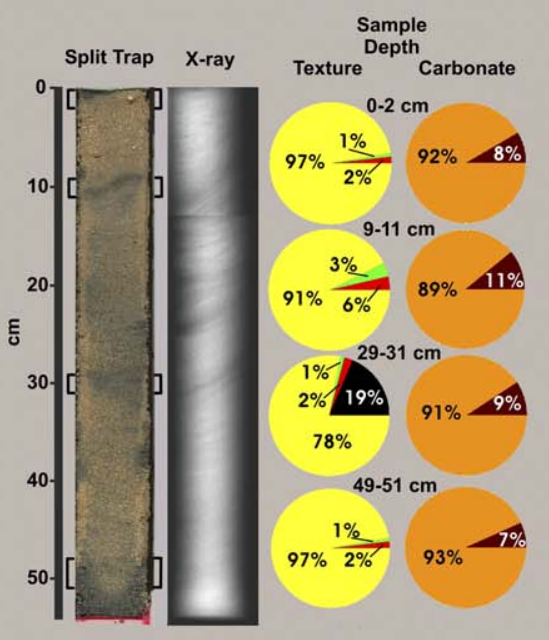

\begin{tabular}{|c|c|}
\hline Key: Texture & Carbonate \\
\hline \% Grave & $\% \mathrm{CaCO}_{3}$ \\
\hline \% Sand & $\% \mathrm{Non} \mathrm{CaCO}_{3}$ \\
\hline \% Sillt & \\
\hline
\end{tabular}

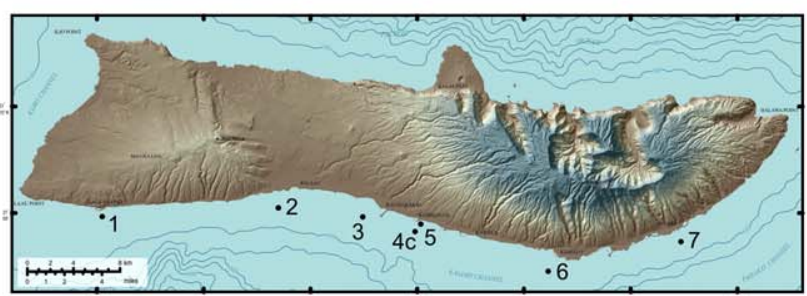

Fig. 3. Stratigraphy of tube traps at four sites along the Molokai reef during the deployment in which Kona storms occurred. Bulk X-rays were taken of unsplit tubes at the Molokai General Hospital. Photographs are of tube traps split lengthwise. Brackets at the sides of the photograph show the sampling intervals (parallel to bedding planes in 4c). Sediment texture and \%carbonate - \%non-carbonate (NC) are indicated with pie diagrams. Water depth in meters and meters above bottom (mab) is listed in the header for each site plot. The horizontal line at approximately $10 \mathrm{~cm}$ depth in the X-ray (see $4 \mathrm{c}$ ) is the joint between X-ray films.

The $27-29 \mathrm{~cm}$ horizon, sampled parallel to the horizon boundaries, has significantly higher silt + clay $(40 \%)$, non-carbonate $(27 \%)$, and magnetite abundance, than other horizons in the trap. Although it is not possible to assign dates to deposits within the tube trap, we interpret this horizon as a pulse of land-derived material that was 
transported over the reef crest and deposited in the trap during or after the storm. Compared to a horizon deposited earlier, possibly before the storm, percentages of both mud and non-carbonate in the $27-29 \mathrm{~cm}$ horizon increased by a factor of 2.5 , and magnetite increased by a factor of 4.5. This is the best example of presumed flood material that accumulated in traps beyond the reef crest.

The trap at site $4 \mathrm{c}$ at $4.9 \mathrm{~m}$ (Fig. 3) is located in an anomalous region about $6 \mathrm{~km}$ in length along the reef crest where live coral coverage is $<12 \%$, as compared to $80-90 \%$ elsewhere (Jokiel, 2004). Ogston et al. (2004) and Storlazzi et al. (2004a) note that this anomalous region is exposed to elevated suspended sediment concentrations resulting from offshore transport of reef flat material resuspended by trade wind waves, swell, and local circulation. These authors point out, however, that a causal linkage between offshore sediment transport and the low coverage of living coral in this region has not been confirmed.

Tube traps from Hale O'lono and Pukoo (Fig. 3, sites 1 and 7) were completely filled during the deployment that included Kona storms, and therefore the collection rate estimates constitute a lower limit $\left(>7400 \mathrm{~g} / \mathrm{m}^{2} /\right.$ day and $>6400 \mathrm{~g} / \mathrm{m}^{2} /$ day, respectively). The texture of the trapped sediments at these sites is $>78 \%$ sand, and the carbonate contents within both traps fall between $87 \%$ and $94 \%$, indicating a consistent predominance of reef-derived material in each horizon selected. There was no evidence of increased land-derived material during the flood period from visual or X-ray assessment of trapped sediment. At site 7, the trapped sediments in the $29-31 \mathrm{~cm}$ horizon are $19 \%$ gravel-sized particles that would suggest a period of higher wave-induced bottom stress. At site 1 , in the $7-$ $11 \mathrm{~cm}$ depth interval, an increase in gravel-sized particles in trapped sediment may also suggest higher bottom stress; however, the increase also could result from a change in the particle collection efficiency as the trap filled and brought the level of accumulating sediment closer to the turbulence at the trap opening. The instruments providing bottom stress data at sites 1 and 7 failed during this deployment period.

\subsection{Time-series traps}

The timing of sediment mobility/resuspension events at Palaau and Kamiloloa (Fig. 1, sites $2 \mathrm{~b}$ and $4 \mathrm{a}$ ) can be determined with the 4.5-day resolution of the time-series traps. There were 15 peaks in collection rate at Palaau when both traps were working properly (Fig. 4). Of these, seven peaks correspond with a peak in the same sampling interval at Kamiloloa (single red bar in both plots of Fig. 4), and six other nearly corresponding peaks are offset by one 4.5-day interval (blue bars in Fig. 4). The close agreement in timing supports the expected finding that major wave events typically impact a wide region of the reef.

The time-series data at Palaau during the period of Kona storms (Fig. 5) reveal a close correspondence in tim- ing of peaks in bottom stress and collection rate. The correlation between bottom stress and collection rate for each 4.5-day sampling interval is high $\left(r^{2}=0.73\right)$. In this deployment however, as well as in others, there are examples of the collection rate differing by a factor of 2 , while the maximum bottom stress is essentially the same (bottles 12 and 17, Fig. 5). Such discrepancies illustrate the potential complexities in the response of traps to parameters other than bottom stress. These may include variations in local tide and wind-induced currents, swell directions, and amounts of sediment available for resuspension. Another variable is the trap efficiency that is difficult to quantify in near-bottom oscillatory currents generated by waves.

The rainfall associated with the Kona storms during bottle intervals 3 and 17 exceeded $4 \mathrm{~cm} /$ day (Fig. 5) and generated significant floods. During the interval of bottle 12 , very low rainfall was recorded, yet the collection rate was similar to interval 3 . These trap samples, collected in well-defined time intervals, were used to evaluate the influence of floods on composition and mass of trapped sediment.

\subsection{Time-series traps composition}

The carbonate content of the sediment trap material clearly shows that particles collected by the traps are predominantly from the reef. At the time-series trap site on the fore reef off Kamiloloa (Fig. 1, site 4a), most of the carbonate contents in pre-storm samples (August 6-November 24,2001$)$ are within the narrow range of $64-69 \%$ (mean $66 \% \pm 2 \%$ ) with the exception of two samples at $55 \%$ and 57\% (bottles 6 and 20, respectively, Fig. 6). These low values were on samples collected when the collection rate was $<1.5 \mathrm{~g} / \mathrm{m}^{2} /$ day, the lowest of deployment 3 . Such low collection rates imply low resuspension, high water clarity, and a period when fine-grained, land-derived particles can settle into the traps with minimal dilution from locally resuspended carbonate-rich bottom sediments that make up the seabed at this location.

The carbonate content of trapped sediment collected during the first Kona storm at Kamiloloa (Fig. 6b, bottle 4-3) is within the range of pre-storm values. This sampling period experienced high bottom stress and high rainfall. The sample representing the second peak in trap collection rate (bottle 4-6) has the highest percentage carbonate, and corresponds in time with modest bottom stress but no rain. There is no clear explanation for the fact that the peak in collection rate of bottle 4-6 does not match a peak in bottom stress that occurs at the time of bottle 4-7. The higher carbonate content in bottle 4-6 compared to bottle 4-3 (during the storm) may reflect carbonate sediment newly made available from the carbonate substrate perhaps by waves reworking the seabed during the first major wave event.

A contribution of land-derived material in the timeseries trap at Kamiloloa is suggested from five samples within the ellipse in Fig. 6 (bottles 4-4, -5, -7, -8, -9) 
Time-Series Trap Collection Rates with Time:

Palaau and Kamiloloa
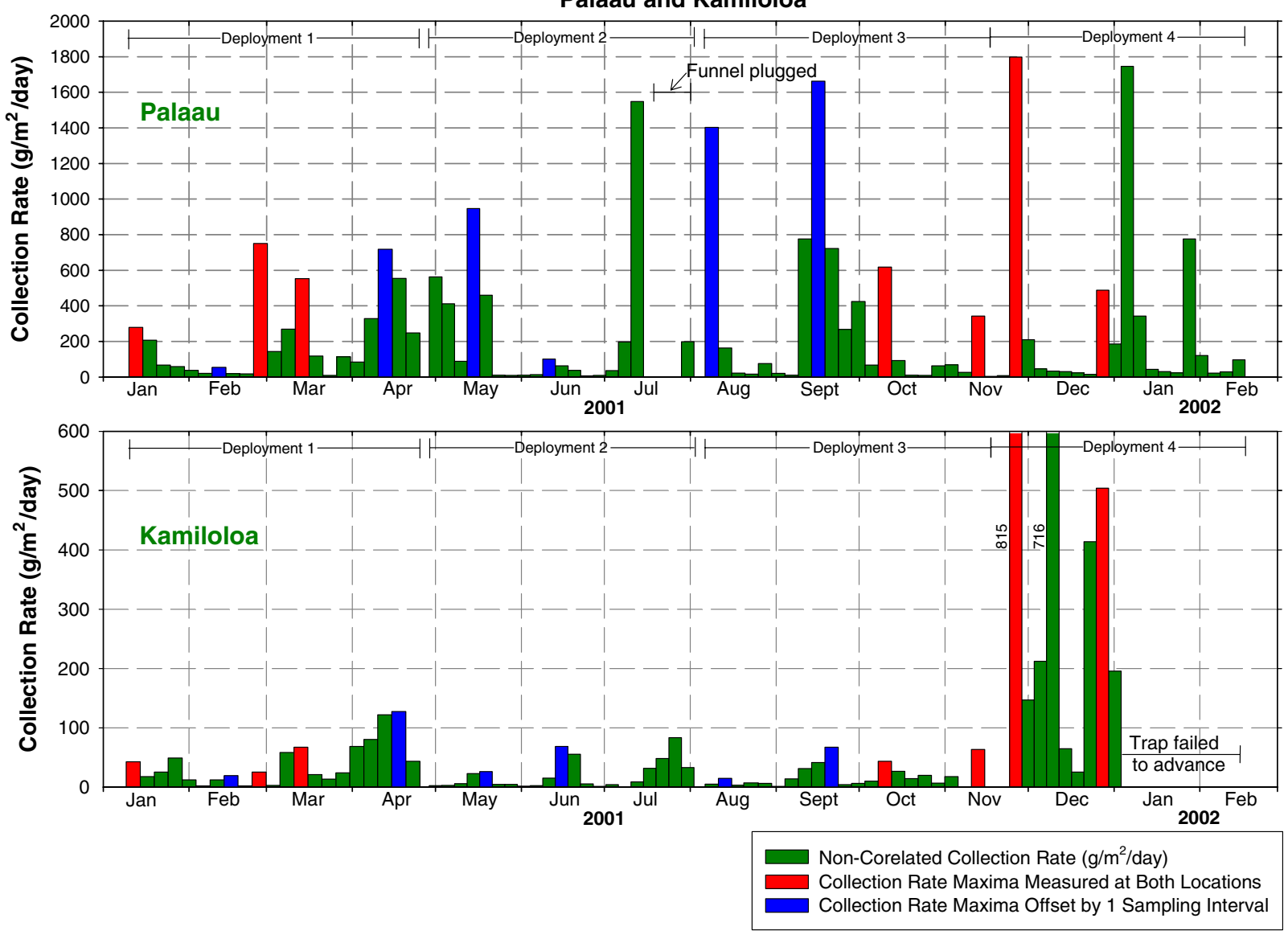

Note: $Y$-axes are of different scales.

Fig. 4. Histogram showing the collection rates $\left(\mathrm{g} / \mathrm{m}^{2} /\right.$ day) with time at Palaau and Kamiloloa. Red bars represent maxima in collection rates that are synchronous at both locations. Blue bars represent maxima in collection rates that agree in timing at both locations within one 4.5-day sampling interval. The green bars represent all other samples. The similarities in timing of peaks in collection rate at these two locations indicate that wide areas of the reef are impacted by the same wave events.

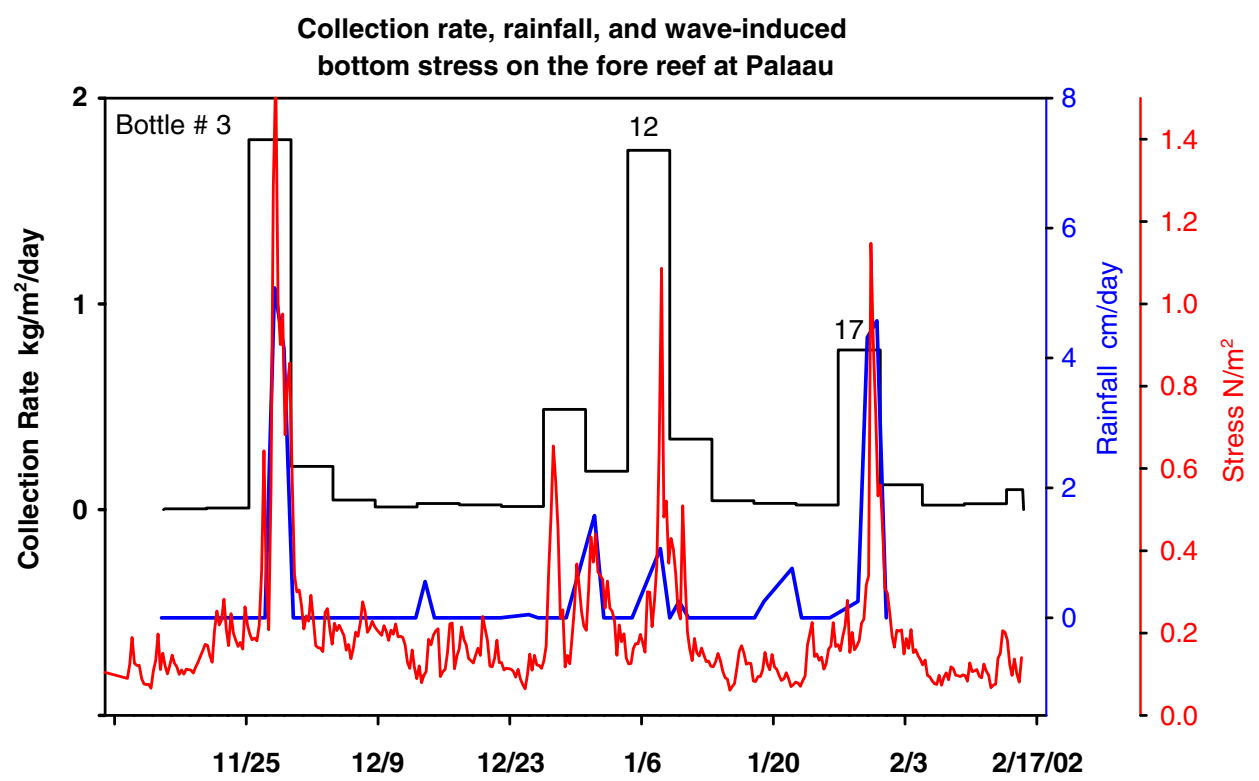

Fig. 5. Palaau (site 2, Fig. 1) time-series trap collection rate, rainfall, and wave-induced bottom stress during the deployment that included two major Kona storms and a number of minor rainfall events. 


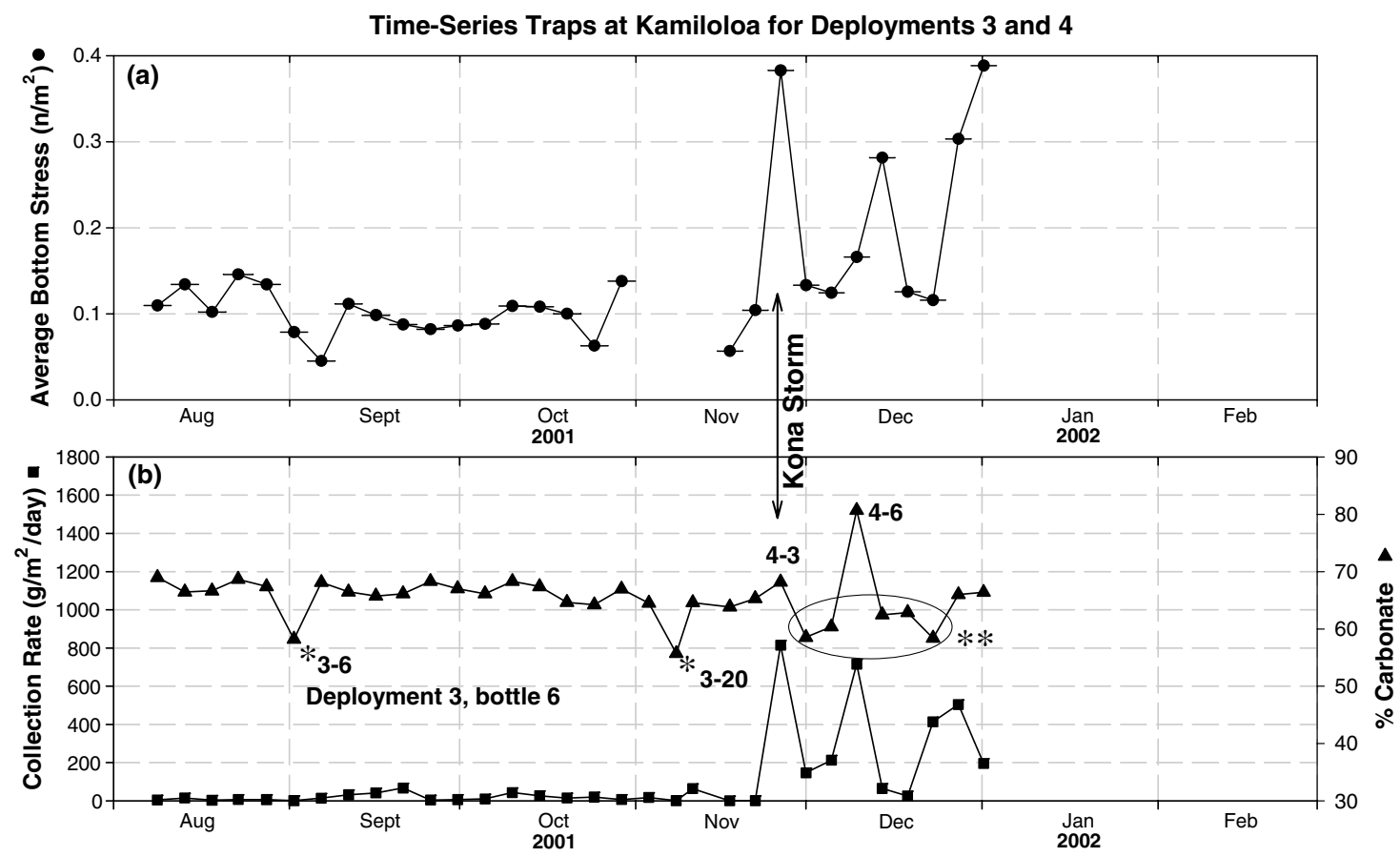

Fig. 6. (a) Average bottom stress during the interval of each trap bottle at Kamiloloa from August 6, 2001 to January 7, 2002 when the batteries failed. (b) Trap collection rate and $\%$ carbonate. * Indicates two samples of small mass because collection rate was $<1.5 \mathrm{~g} / \mathrm{m}^{2} / \mathrm{d}$. ** These five samples within ellipse have carbonate values lower than pre-flood samples, consistent with a 10\% increase in land-derived material to the trap following the Kona storm.

Time-Series Traps at Palaau for Deployments 3 and 4

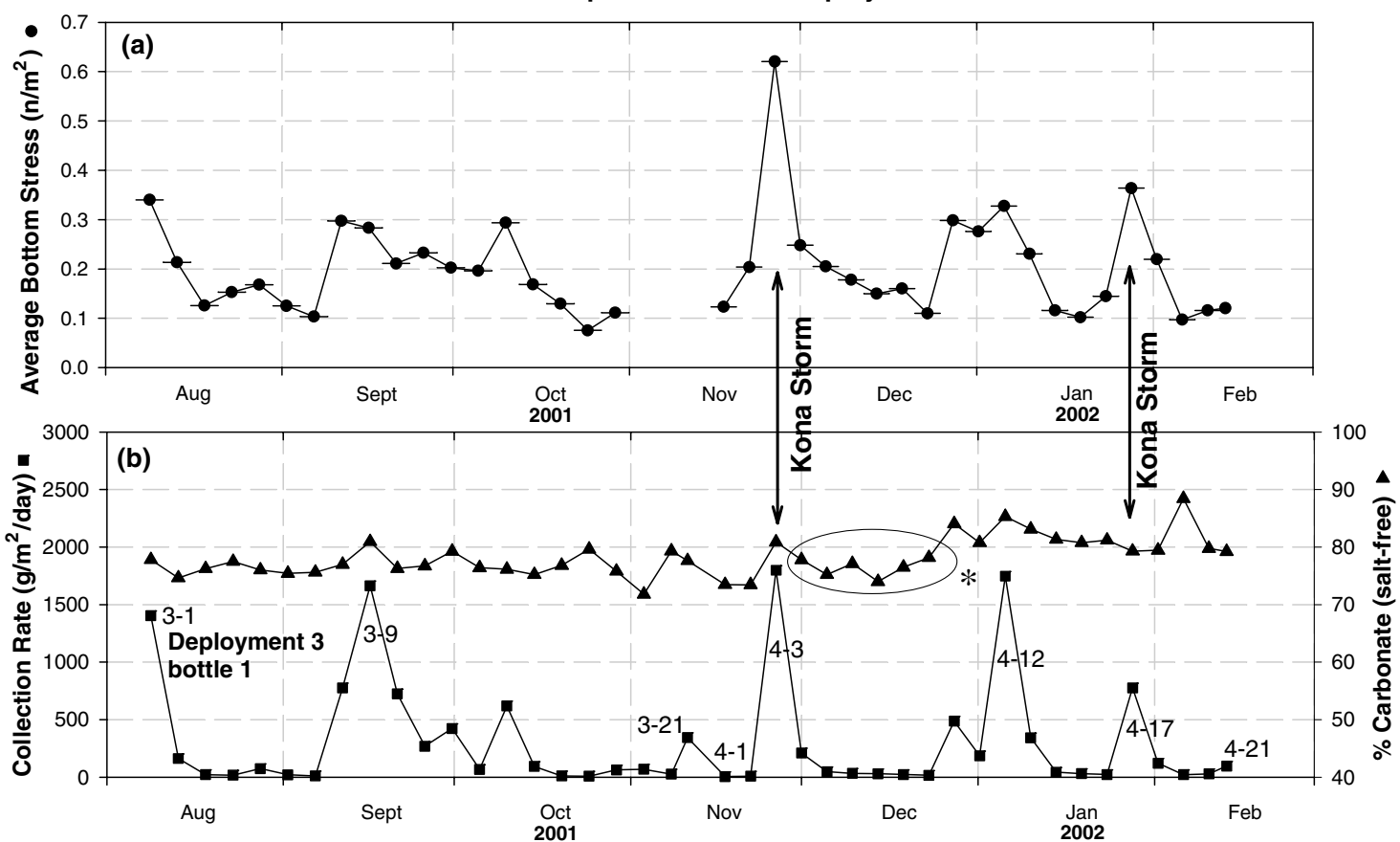

Fig. 7. (a) Average bottom stress during the interval of each trap bottle at Palaau from August 6, 2001 to February 14, 2002. (b) Trap collection rate and $\%$ carbonate. * Indicates post-storm samples at Palaau that were collected at the same time as samples from Kamiloloa circled in Fig. 6b. At Palaau the post-flood carbonate values are the same or higher than pre-storm values, suggesting no measurable increase in land-derived material following the floods.

collected during periods of low or moderate collection rates following the major storm represented in bottle 4-3. The average carbonate value of these samples is $61 \% \pm 2 \%$, sig- nificantly lower than the pre-storm average of $66 \%$. The compositional shift from $66 \%$ to $61 \%$ carbonate suggests a minor increase in the proportion of land-derived material 
collected in the trap following the high runoff event from the island.

At Palaau (Fig. 1, site 2a), the average concentration of carbonate in pre-storm samples $(76 \pm 2 \%)$ is identical to the post-Kona storm samples (Fig. 7b; bottles 4-4 through $4-9$ ). Hence there is no signal from the flood-derived sediment in the time-series trap samples at this location. The typically higher collection rate at Palaau (compared to Kamiloloa) may more effectively dilute any new material added by the flood. It is interesting to note that the average carbonate content in samples from December 30, 2001 to the end of the deployment is slightly higher $(82 \pm 3 \%)$ than the samples collected before or immediately after the first Kona storm. This may be another case where storm waves reworked the carbonate substrate and increased the availability of high carbonate sediment for subsequent resuspension, transport, and collection.

The minor change in the composition of trapped sediment collected on the fore reef off Kamiloloa during the flood period, and the lack of compositional change at Palaau, suggest that land-derived sediment delivered during a major flood and wave event has a low potential for burying or smothering coral on the fore reef. The potential for settling particles to be retained in sediment traps is much greater than on the adjacent turbulence-exposed surface of the coral reef. The evidence that flood-derived material does not accumulate in traps along the fore reef in sufficient quantity to significantly change composition, indicates that this material is unlikely to accumulate on the adjacent surface of living corals.

Turbidity associated with transient suspended sediment on the fore reef may be a source of incremental stress to reef health (Rogers, 1990). The frequency and relative magnitude of events inferred from the time-series sediment trap collections suggest that the fore reef is often exposed to increased turbidity from resuspended bottom sediments. Turbidity in surface water over the fore reef was also documented by photography of sediment-laden plumes following the rare Kona storms (Field et al., in press), or of plumes generated on the reef flat when high-wind events coincided with high tide (Ogston et al., 2004; Storlazzi et al., 2004a). The variability in light levels needed for photosynthesis by the algae living in coral of the fore reef was not measured, but these observations suggest that turbidity is introduced periodically to both surface and bottom waters and would at least temporarily reduce light levels.

\subsection{Metal concentrations in sediment trap material}

The concentrations of metals in trapped sediments are low (Table 1) compared to the toxic effects guidelines that are often used to estimate the degree of contamination in coastal sediments by regulatory agencies (Long et al., 1995). None exceed the ERM (effects range - medium) guideline, and the average concentrations are below the ERL (effects range - low) values except for arsenic, which is $4 \mathrm{ppm}$ above the ERL. Low concentrations of heavy metals are not surprising because there are no mining or metal-related industries on Molokai, and there are no ocean outfalls for sewage. Sewage from the town of Kaunakakai $\left(950 \mathrm{~m}^{3} /\right.$ day from a population of 2700$)$ undergoes secondary treatment with disposal of dry sludge to a landfill and discharge of treated effluent into injection wells. An impact on the reef from seaward migration of groundwater containing sewage effluent from the treatment plant or from private septic systems outside of the Kaunakakai district has not been observed (John Souza, Department of Waste Water Reclamation, Molokai, personal communication, 2004).

The concentrations of heavy metals correlate strongly with concentrations of $\mathrm{Fe}$, one of the major elements in Molokai's basaltic red soil, indicating that they are associated with the land-derived fraction of the trapped sediment. The plot of $\mathrm{Cu}$ against $\mathrm{Fe}$ in trap samples defines two populations (Fig. 8) and provides insight into sediment transport processes in this reef system. The data group with lower slope contains trap results from a transect off Kamiloloa (Fig. 2; $0.9 \mathrm{~m}, 4.9 \mathrm{~m}$, and $11.5 \mathrm{~m}$ water depths). The nearly constant $\mathrm{Cu} / \mathrm{Fe}$ ratio from inshore to offshore supports the conclusion of Storlazzi et al. (2004a) and Ogston et al. (2004) that there is some cross-reef transport of suspended sediment from the reef flat to beyond the reef crest. The second data group of samples, primarily from Palaau, has a distinctly higher slope. Both data groups have samples from before, during, and after the Kona storms. The fact that there is no difference in slope following the storm, suggests that the composition (as defined by the $\mathrm{Cu} / \mathrm{Fe}$ ratio) of the 2001 storm material is not appreciably

Table 1

Average concentrations of metals (ppm dry weight, salt free) in sediment trap samples from Molokai compared to toxicity guidelines

\begin{tabular}{|c|c|c|c|c|c|c|c|c|c|}
\hline & Arsenic & Cadmium & Chromium & Copper $^{\mathrm{a}}$ & Mercury $^{\mathrm{a}}$ & Nickel & Silver $^{\mathrm{a}}$ & Lead & Zinc $^{a}$ \\
\hline \multicolumn{10}{|c|}{ This Study } \\
\hline Mean & 12.0 & 0.053 & 32.6 & 10.4 & 0.023 & 16.6 & 0.19 & 2.9 & 31.2 \\
\hline Std. dev. & 4.1 & 0.048 & 17.6 & 6.4 & 0.007 & 4.5 & 0.28 & 1.8 & 31.1 \\
\hline $\mathrm{ERM}^{\mathrm{b}}$ & 70 & 9.6 & 370 & 270 & 0.71 & 51.8 & 3.7 & 218 & 410 \\
\hline $\mathrm{ERL}^{\mathrm{b}}$ & 8.2 & 2.1 & 81 & 34 & 0.15 & 20.9 & 1 & 46.7 & 150 \\
\hline
\end{tabular}

a Mean values are slightly elevated because the detection limit was assigned to concentrations below analytical detection.

b Toxicity guidelines from Long et al. (1995). 
Iron vs. Copper in Sediment Trap Samples from Molokai

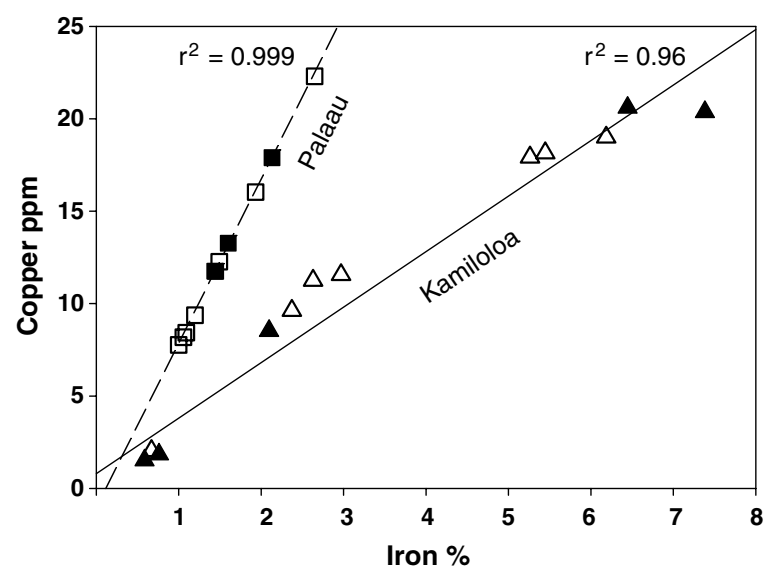

Fig. 8. The concentrations of iron and copper are highly correlated within trap samples from Palaau (squares, dashed line) and Kamiloloa (triangles, solid line). The different slopes suggest a different composition and source of the land-derived material. The range of metal concentrations reflects variable dilution by reef-derived carbonate sediment. Flood period data are shown in solid symbols, pre- and post-flood data in open symbols. The high linearity in $\mathrm{Cu} / \mathrm{Fe}$ ratio among trap samples from flood and nonflood periods suggests that composition was not changed by the floods.

different than material previously added to the reef system. The clearly different $\mathrm{Cu} / \mathrm{Fe}$ slopes at Kamiloloa and Palaau suggest the influence of a different land-derived source for each of these two locations.

\subsection{Magnetic properties of sediment trap material}

Magnetic properties in coastal sediments off Molokai are a specific indication of the land-derived component because the biogenic carbonate is non-magnetic. The volcanic rocks forming the Hawaiian Islands contain magnetite that imparts characteristic magnetic properties to the volcanic rocks and to the soils that develop from them. Land-derived particles carry their magnetic signature, potentially altered by weathering processes, as they are transported to and within the coastal ocean by streams, wind, and currents. The magnetic properties of the trapped sediment provide additional evidence of land-derived material at all locations along the reef with no change in composition following Kona storms.

From a comprehensive magnetic analysis on selected sediment trap samples, two properties, isothermal remanent magnetization (IRM) and anhysteretic remanent magnetization (ARM), were found to provide the most useful information about trends along the reef. IRM and ARM were easily detected in all the samples of trapped sediment, indicating that land-derived magnetite makes up a measurable fraction of the actively mobile sediment throughout the reef system. IRM increases as carbonate decreases at both Kamiloloa and Palaau fore reef sites, but with different slopes (Fig. 9). These linear relations are interpreted to be mixing lines with a land-derived end-member having higher concentration of magnetite at Kamiloloa than at Palaau.
Isothermal remanent magnetization (IRM) vs \% Carbonate in trap samples from Palaauand Kamiloloa

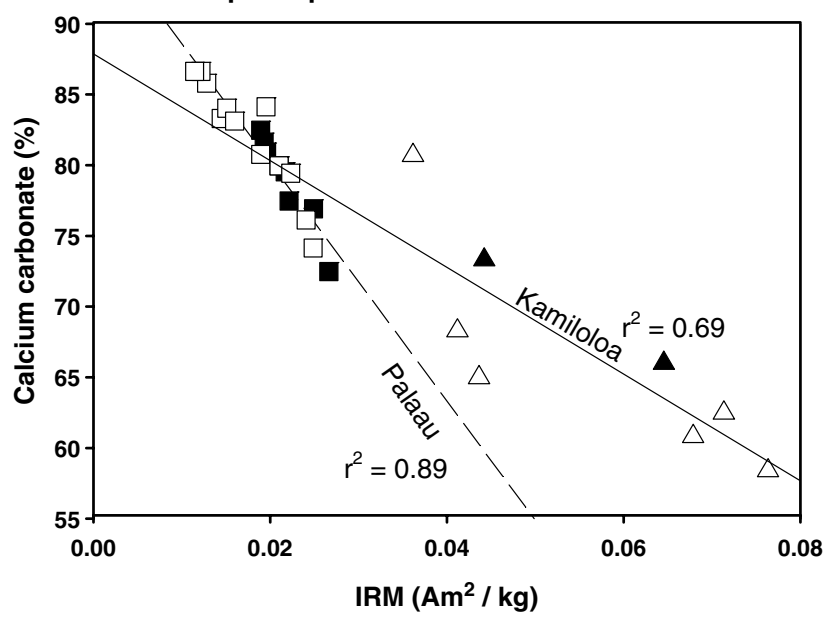

Fig. 9. The different regression lines for isothermal remanent magnetization (IRM) vs. \% calcium carbonate in trap samples from Palaau (site 2; squares, dashed line) and Kamiloloa (site 4;triangles, solid line) indicate higher magnetite concentration in the land-derived sediment at Kamiloloa. Data from flood periods (solid symbols) plot with the same slope as data from pre- and post-flood periods (open symbols). These trends provide further evidence that floods did not significantly alter the composition of trapped sediment.

The relationships in Fig. 9 include storm and non-storm samples on the fore reef. There are no significant or consistent increases in IRM (magnetite) relative to carbonate in trap samples collected during or after storms. This suggests that the Kona storms did not markedly increase the landderived component of suspended sediments that are captured by traps on the fore reef. This conclusion is supported by the uniform non-carbonate percentage in pre- and post-storm samples.

The ARM/IRM ratio provides information about magnetic grain size of a population of magnetic grains, independent of the abundance of magnetic minerals. ARM/ IRM values increase with decreasing magnetic grain size. Magnetic grain size can be influenced by a number of factors, among them the cooling history of the igneous rock in which magnetic minerals formed and by the influence of weathering or other types of alteration such as diagenesis involving post-depositional destruction of magnetite. Petrographic examination of trap samples shows no evidence of post-depositional alteration. ARM/IRM is independent of dilution by carbonate sediments and may be used as an indicator of sediment source in this reef system. Plots of ARM/IRM ratios against carbonate show the similarity of values within sample sites and the differences between sites (Fig. 10).

In trap samples from Palaau the ARM/IRM ratios range from 0.057 to 0.066 and are the highest within this study area. There is no difference between samples collected during tranquil periods of low collection rate (low bottom stress) or during the combined wave and flood events at the end of the study period. 
Magnetic Properties (ARM/IRM) of Sediment Trap Material

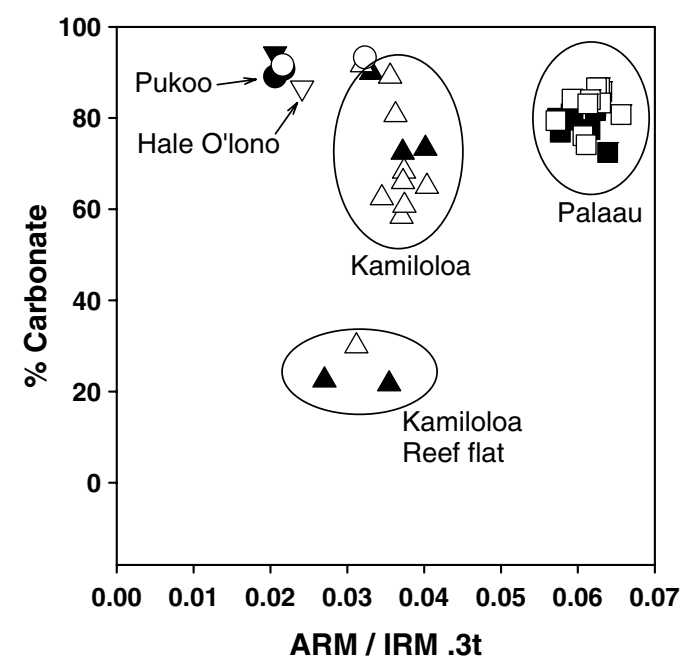

Fig. 10. Plot of the ARM/IRM ratio vs. \% carbonate $(\mathrm{ARM} / \mathrm{IRM}=$ anhysteretic remanent magnetization to isothermal remanent magnetization at $0.3 \mathrm{~T}$ ). Ellipses include flood (solid symbol) and non-flood (open symbol) samples from discrete areas. Results from Palaau cluster closely together suggesting a unique source, character, or weathering history of the magnetic particles in the resuspended sediments from Palaau.

At Kamiloloa, $12 \mathrm{~km}$ to the east from Palaau, ARM/ IRM ratios are between 0.027 and 0.040 at both the inshore reef flat location ( $1 \mathrm{~m}$ water depth) and at the fore reef location (10.1 m water depth). Sediment traps at the east and west end of the reef, Pukoo and Hale O'lono, respectively, have similar but low ARM/IRM ratios $(0.021-$ 0.032 ).

The groupings of ARM/IRM ratios in sediment traps in different geographic regions could reflect distinct properties of volcanic rocks in the local source areas, a different weathering history of the particles in rock and (or) soil, different stages of sorting during particle transport, or some combination of all three factors. Although these possible explanations have not yet been tested, we note a number of unique aspects of the land surface adjacent to Palaau traps that may influence magnetic properties of sediments entering the sea. The land surface at Palaau is characterized by low relief, by a high degree of bedrock weathering, and by agricultural activity over wide areas, some with three growing cycles per year. These factors indicate a system vulnerable to low-energy sediment transport processes from an altered, frequently tilled surface.

The direction of fine-grained suspended sediment transport measured by seabed instrumentation on the reef flat and on the fore reef at Kamiloloa is both across reef and along reef to the west (Ogston et al., 2004; Storlazzi et al., 2004a). The similar ARM/IRM ratios for reef flat and fore reef locations off Kamiloloa are consistent with cross-shelf transport of particles. The different ARM/ IRM ratios for Kamiloloa and Palaau are interpreted to indicate a lack of sediment transport between these two sites for the type of sediment preferentially collected by traps. The Kaunakakai wharf between Kamiloloa and Palaau (Fig. 1) may be an impediment to the east-to-west transport of resuspended particles collected in traps.

\section{Summary and conclusions}

1. Land-derived sediment, identified by the non-carbonate fraction and the presence of magnetite, is a ubiquitous component of sediment trap material collected from all trap sites within the Molokai reef system. This indicates that fine-grained terrestrial sediment is constantly moving through the Molokai reef system. It represents approximately $70 \%$ of the total sediment trap material on the reef flat off Kamiloloa and $6-40 \%$ on the fore reef.

2. Following the Kona storms and floods beginning in late November 2001, we measured an increase in the landderived fraction in trapped sediment at three trap sites in a transect off Kamiloloa. The floods appeared to recharge the reef flat with land-derived material, increasing the land-derived fraction from $59 \%$ to $75 \%$. A trap at $5 \mathrm{~m}$ water depth on the fore reef documented transport of land-derived material over the reef crest and onto the fore reef. The trap at $11.5 \mathrm{~m}$ water depth at Kamiloloa showed only a minor increase in the land-derived fraction and no increases were observed at other 10-12 m trap sites along the reef crest. These patterns indicate that land-derived sediment delivered during a major flood accompanied by high waves has a low potential for burying or smothering coral on the fore reef. One potential impact of flood-derived sediment would potentially be periodic high turbidity and exposure of coral to the suspended fine-grained particles. Although specific measurements of these parameters were not made, they are not expected to be significant because flood-derived high turbidity has a duration of only a few days (Field et al., in press), and the toxic-metal concentrations are low in trap samples containing the highest fraction of flood-derived sediment.

3. We observed consistent regional differences in the relative magnitude of sediment collection rates that correlated with regional differences in wave-induced bottom stress. This observation indicates that waves are the primary cause of sediment resuspension. Among the different areas along the reef, the following order of resuspension intensity was observed from highest to lowest: Hale O'lono, Pukoo, Palaau, Kamiloloa, and Kamalo. This order reflects the greater wave exposure on the west and east ends of the reef and the more tranquil central region that is partially sheltered by neighboring islands.

4. During the deployment of tube traps that included the Kona storms of November 2001 and January 2002, the 3-month average collection rates were higher than during non-storm periods by $1.3 \times$ at Palaau and $39 \times$ at Kamalo. At Kamiloloa, Hale O’lono, and Pukoo 
the collection rates were at least $10 \times$ higher during the storm than non-storm periods. At these sites the tube traps were completely filled prior to recovery, thus providing a minimum estimate. The time-series traps with 4.5-day resolution revealed that Kona storms increased the collection rate by more than a factor of $1000 \times$ compared to non-storm intervals. Good agreement was observed in the timing of peak resuspension events measured in time-series traps at two locations $12.3 \mathrm{~km}$ apart. This observation indicated that the same wave events caused resuspension along wide areas of the fore reef.

5. A high correlation coefficient $\left(r^{2}=0.73\right)$ was measured between wave-induced bottom stress and collection rate in time-series traps at Palaau during the deployment containing Kona storms. Lower correlations during other deployments indicate that factors other than bottom stress may influence the trap collection rate in this energetic coastal area. Important potential factors that were not documented include speed and direction of local currents, wave direction, sediment availability, and the differences in collection efficiency of traps in oscillatory currents.

6. The ratio of anhysteretic remanent magnetization (ARM) to isothermal remanent magnetization (IRM) indicates magnetic grain size in a population of magnetic grains, independent of the abundance of magnetic minerals or dilution by carbonate. This ratio is distinct and uniform in a transect from the reef flat to beyond the reef crest at Kamiloloa, supporting the hypothesis of some cross-reef transport (Ogston et al., 2004; Storlazzi et al., 2004a). Off Palaau, the ratio is highest and within a narrow range. Identification of the source of particles at Palaau with the distinctive magnetic signature will be part of a continuing study.

7. The concentrations of heavy metals in the trapped sediment within the reef system off Molokai are well below effects range-medium (ERM) toxicity guidelines for coastal sediments (Long et al., 1995). Specific guidelines for metal concentrations in sediments keyed to health of coral, however, do not yet exist. The $\mathrm{Cu} / \mathrm{Fe}$ ratios in trapped sediment may be another index, similar to magnetic signatures, that may identify different source areas of land-derived material to the reef system.

\section{Acknowledgements}

We thank Joe Reich, captain of the R.V. Alyce C., for his outstanding assistance at sea and the Molokai General Hospital for taking X-rays of our sediment samples. We also extend thanks to Rick Rendigs and Susie CochranMarquez for assistance with traps and logistics in the field, to Ray Davis for the diver-friendly tripod design, to Paul Lamothe for metals analyses, to Simon Barber and Charlene Tetlak for textural analyses, and to Sandy Milbert and Josh Logan for graphics. Chuck Holmes and Page
Valentine provided helpful comments on an early version of the manuscript.

\section{References}

Anthony, K.R.N., 2000. Enhanced particle-feeding capacity of corals on turbid reefs (Great Barrier Reef, Australia). Coral Reefs 19, 59-67.

Bak, R.P.M., 1978. Lethal and sublethal effects of dredging on reef corals. Marine Pollution Bulletin 9 (1), 14-16.

Baker, E.T., Milburn, H.B., Tennant, D.A., 1988. Field assessment of sediment trap efficiency under varying flow conditions. Journal of Marine Research 46, 573-592.

Barber, S.G., 2002. Laboratory Procedures and Grain Size Analysis of Terrigenous and Carbonaceous Sediment of the Fringing Reef of Molokai, Hawaii. Thesis, San Francisco State University, San Francisco, CA. Appendix A, pp. 4-13.

Briggs, P.H., Meier, A.L., 1999. The determination of forty-two elements in geological materials by inductively coupled plasma-mass spectrometry. US Geological Survey Open-File Report 99-166, 7p.

Calhoun, R.S., Field, M.E., 2002. Beach and reef flat sediment along the south shore of Molokai Hawaii. In: Carbonate Beaches, 2000, Proceedings volume. American Society of Civil Engineers, pp. 163171.

Field, M.E., Bothner, M.H., Chavez, P.S., Jr., Cochran-Marquez, S.A., Jokiel, P.L., Ogston, A.S., Storlazzi, C.D., in press. Fate of flood sediment on a fringing coral reef, Molokai, Hawaii. In: Tenth International Coral Reef Symposium, Okinawa, Japan, June 28-July 2, 2004.

Hayward, A.B., 1982. Coral reefs in clastic sedimentary environments: fossils (Miocene, SW Turkey) and moderns (recent, Red Sea) analogs. Coral Reefs 1 (2), 109-114.

Honjo, S., 1980. Material fluxes and modes of sedimentation in the mesopelagic and bathypelagic zones. Journal of Marine Research 38, 53-97.

Jokiel, P.L., Brown, E.K., Friedlander, A., Rodgers, K.S., Williams, W.R., 2004. Hawaii coral reef assessment and monitoring program: spatial patterns and temporal dynamics in reef coral communities. Pacific Science 58 (2), 159-174.

Jokiel, P.L., University of Hawaii, Hawaii Institute of Marine Biology, Kaneohe, Hawaii. Written communication, 2004.

Jonsson, I.G., 1966. Wave Boundary Layers and Friction Factors. In: Proceedings of the 10th International Conference on Coastal Engineering, pp. 127-148.

Lamothe, P.J., Meier, A.L., Wilson, S., 1999. The determination of fortyfour elements in aqueous samples by inductively coupled plasmamass spectrometry. US Geological Survey Open-File Report 99-151, pp. $1-14$.

Long, E.R., MacDonald, D.D., Smith, S.L., Calder, D.F., 1995. Incidence of adverse biological effects within ranges of chemical concentrations in marine and estuarine sediments. Environmental Management 19 (1), 81-97.

McLane Research Laboratories, Inc., 2004. Time-series sediment trap. Description available online at: <http://www.mclanelabs.com/ mark $78 \mathrm{~g} 21 . \mathrm{html}>$.

Moberly, R.M., Chaimberlin, T., 1964. Hawaiian Beach Systems. University of Hawaii, 95p.

Nielsen, P., 1992. Coastal Bottom Boundary Layers and Sediment Transport. World Scientific, Singapore, p. 324.

Nugues, M.M., Roberts, C.M., 2003. Coral mortality and interaction with algae in relation to sedimentation. Coral Reefs 22, 507-516.

Ogston, A.S., Storlazzi, C.D., Field, M.E., Presto, M.K., 2004. Currents and suspended sediment transport on a shallow reef flat: South-central Molokai, Hawaii. Coral Reefs 23 (4), 559-569.

Presto, M.K., Ogston, A.S., Storlazzi, C.D., Field, M.E., 2006. Seasonal and spatial controls on terrigenous sediment dispersal on a shallow fringing reef flat, Molokai, Hawaii. Estuarine, Coastal and Shelf Science 67, 67-81. 
Risk, M.J., Erdman, M.V., 2000. Isotopic composition of nitrogen in stomatopod tissues as an indicator of human sewage impacts on Indonesian coral reefs. Marine Pollution Bulletin 40, 50-58.

Roberts, L.M., 2001. Historical land use, coastal change, and sedimentation on South Molokai. In: Saxena, N. (Ed.), Recent Advances in marine Science and Technology, 2000. PACON International, pp. 167-176.

Rogers, C.S., 1990. Responses of coral reefs and reef organisms to sedimentation. Marine Ecology Progress Series 62, 185-202.

Rosenfeld, M., Fresler, V., Abelson, A., 1999. Sediment as a possible source of food for corals. Ecology Letters 2, 345-348.

Storlazzi, C.D., Logan, J.B., Field, M.E., 2003. Quantitative morphology of a fringing reef from high-resolution laser bathymetry: Southern Molokai, Hawaii. Geological Society of America Bulletin 115, 1344 1355 .
Storlazzi, C.D, Ogston, A.S., Bothner, M.H., Field, M.E., Presto, M.K., 2004a. Wave- and tidally-driven flow and sediment flux across a fringing coral reef: Southern Molokai, Hawaii. Continental Shelf Research 24, 1397-1419.

Storlazzi, C.D., Field, M.E., Rogers, K., Jokiel, P.L., Brown, E., Dykes, J.D., 2004b. A model for wave control on coral breakage and species distribution in the Hawaiian islands. Coral Reefs 24 (1), 43-55.

Thompson, R., Oldfield, F., 1986. Environmental Magnetism. Allen \& Unwin, London, p. 227.

Wittenberg, M., Hunte, W., 1992. Effects of eutrophication and sedimentation on juvenile corals I. Abundance, mortality and community structure. Marine Biology 112 (1), 131-138.

Woolfe, K.J., Larcombe, P., 1998. Terrigenous sedimentation and coral reef growth: a conceptual framework. Marine Geology 155, 331345. 